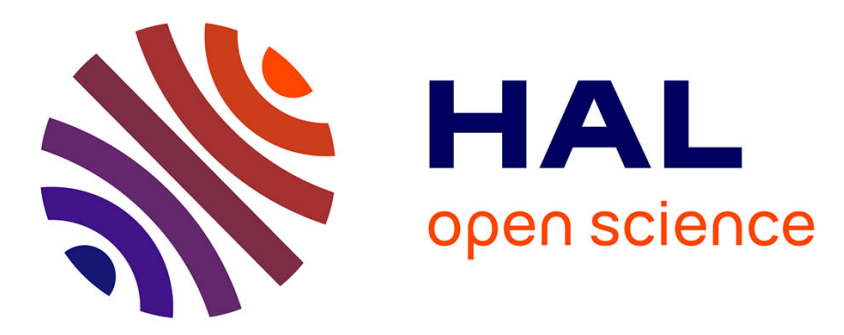

\title{
Discoupling the Ca 2+ -activation from the pore-forming function of the bi-component Panton-Valentine leucocidin in human PMNs
}

\author{
L. Baba Moussa, S. Werner, D.A. A Colin, L. Mourey, J.D. D Pëdelacq, J.P. \\ P Samama, A. Sanni, H. Monteil, G. Prëvost
}

\section{To cite this version:}

L. Baba Moussa, S. Werner, D.A. A Colin, L. Mourey, J.D. D Pëdelacq, et al.. Discoupling the Ca 2+ -activation from the pore-forming function of the bi-component Panton-Valentine leucocidin in human PMNs. FEBS Letters, 1999, 461 (3), pp.280-286. 10.1016/s0014-5793(99)01453-2 . hal-03004456

\section{HAL Id: hal-03004456 \\ https://cnrs.hal.science/hal-03004456}

Submitted on 20 Nov 2020

HAL is a multi-disciplinary open access archive for the deposit and dissemination of scientific research documents, whether they are published or not. The documents may come from teaching and research institutions in France or abroad, or from public or private research centers.
L'archive ouverte pluridisciplinaire $\mathbf{H A L}$, est destinée au dépôt et à la diffusion de documents scientifiques de niveau recherche, publiés ou non, émanant des établissements d'enseignement et de recherche français ou étrangers, des laboratoires publics ou privés. 


\title{
Discoupling the $\mathrm{Ca}^{2+}$-activation from the pore-forming function of the bi-component Panton-Valentine leucocidin in human PMNs
}

\author{
L. Baba Moussa ${ }^{\mathrm{a}, \mathrm{b}}$, S. Werner ${ }^{\mathrm{a}}$, D.A. Colin ${ }^{\mathrm{a}}$, L. Moureyc, J.D. Pédelacq ${ }^{\mathrm{c}}$, J.P. Samama ${ }^{\mathrm{c}}$, \\ A. Sannib, H. Monteil ${ }^{\mathrm{a}}$, G. Prévost ${ }^{\mathrm{a}, *}$ \\ a UPRES EA-1318, Institut de Bactériologie de la Faculté de Médecine, Université Louis Pasteur-Hôpitaux Universitaires de Strasbourg, \\ 3 rue Koeberlé, F-67000 Strasbourg. France \\ ${ }^{\mathrm{b}}$ Département de Biochimie et de Biologie Cellulaire, Fa.S.T. Université Nationale du Bénin, 4 B.P. 0320, Cotonou, Benin \\ ${ }^{\mathrm{c}}$ Groupe de Cristallographie Biologique, CNRS-IPBS, 205, rte de Narbonne, F-31077 Toulouse Cedex, France
}

Received 20 August 1999; received in revised form 27 September 1999

\begin{abstract}
The consecutive cell activation, including $\mathrm{Ca}^{2+}$ channel opening, and pore formation leading to human neutrophil lysis were the two functions of the staphylococcal PantonValentine leucocidin attempted to be discoupled by site-directed mutagenesis. In a first approach consisting in deletions of the cytoplasmic extremity of the transmembranous domain, we produced a LukF-PV $\Delta$ Ser125-Leu128 with a slightly reduced $\mathrm{Ca}^{2+}$ induction but with a significantly lowered lytic activity when combined with its synergistic protein LukS-PV. The second approach consisted in the modification of charges and/or introduction of a steric hindrance inside the pore, which also led to interesting mutated proteins: LukF-PV G131D, G131W and G130D. The latter had an intact $\mathrm{Ca}^{2+}$ induction ability while the lytic one was 20 -fold diminished. Binding properties and intrinsic pore diameters of these discoupled toxins remained comparable to the wild-type protein. The mutated proteins promoted interleukin-8 secretion, but they were rather inactive in an experimental model. New insights are brought concerning the role of the two functions in the virulence of this bi-component leucotoxin.
\end{abstract}

(C) 1999 Federation of European Biochemical Societies.

Key words: Panton-Valentine leucocidin; Discoupling; $\mathrm{Ca}^{2+} /$ ethidium penetration; Stem domain; Virulence;

Staphylococcus aureus

\section{Introduction}

Staphylococcal bi-component leucotoxins constitute a family of pore-forming toxins [17] acting by the sequential interactions with target membranes of two distinct classes of proteins named S (31-32.5 kDa) and F (34-35.5 kDa). Among these toxins, the Panton-Valentine leucocidin (PVL) was the first to be described [16,23]. PVL is specific of rabbit and human polymorphonuclear cells (PMNs), generating inflammatory response in vitro which involves chemotactic and vasodilatating factors [7,8]. The production of PVL by Staphylococcus aureus strains was associated with necrotising pyodermites such as furuncles [2]. Injections of PVL in a rabbit experimental model induced dermonecrosis $[3,6]$. LukS-PV, one of the two PVL components, binds first to membranes, then allowing the binding of the second component LukF-PV and consecutive biological effects [1,13]. Early effects were recently distinguished by using specific inhibitors

*Corresponding author. Fax: (33) 388251113

E-mail: gilles.prevost@medecine.u-strasbg.fr as first as cell activation triggering $\mathrm{Ca}^{2+}$ metabolism prior to the pore formation or lytic activity, sensitising cells to some monovalent cations [19].

Bi-component leucotoxins belong to the family of poreforming toxins rich in $\beta$-sheet structures. Binding, oligomerisation, pre-pore formation and insertion into the membranes are generally admitted to be essential steps before the pores become functional $[4,10]$. The three-dimensional structures of the water-soluble form of LukF-PV [15] and HlgB [14], two related class $\mathrm{F}$ components composing PVL and $\gamma$-haemolysin, appeared recently. LukF-PV and $\mathrm{HlgB}$ are $70 \%$ identical in sequence, and their three-dimensional structures are very similar, comprising three distinct domains: (1) a $\beta$-sandwich of two six-stranded antiparallel $\beta$-sheets which take part in the cap domain described for the heptameric structure of the $\alpha$ toxin [18], (2) a four-stranded open face $\beta$-sandwich topped by several turns and helical segments which is involved in the rim domain of the $\alpha$-toxin heptamer, (3) a small domain of three $\beta$-sheets (Fig. 3A). From the comparison with the three-dimensional structure of the lipostable heptameric form of the $\alpha$-toxin, the extended stem which constitutes the transmembrane $\beta$-barrel after oligomerisation appeared to be condensed as the three-stranded $\beta$-sheets in the water-soluble monomer. A hydrophobic interface is involved between this domain and the $\beta$-sandwich core. As the stem domain constitutes the transmembrane pore once toxins are assembled and inserted into the membrane (Fig. 3B), it may represent a target for discoupling cell activation from pore-formation of bi-component leucotoxins. Its involvement in these two distinct functions and their respective roles in virulence of the staphylococcal bi-component leucotoxins were investigated.

\section{Materials and methods}

\subsection{Bacterial strains and vectors}

Escherichia coli XL1 Blue cells [recA1 endA1 gyra96 thil hsdR17 supE44 relA1 lac $\left(\mathrm{F}^{\prime}\right.$ proAB lacI ${ }^{\mathrm{q}} \mathrm{Z} \Delta \mathrm{M} 15$ Tn10 $\left(\right.$ tet $\left.\left.\left.^{\mathrm{r}}\right)\right)\right]$ were used as recipient cells after site-directed mutagenesis of recombinant plasmids (Stratagene, Montigny le Bretonneux, France). E. coli BL21 [F-, ompT, hsdS $\left.\left(r B^{-}, m B^{-}\right), g a l\right)$ was used for the overexpression of glutathione $S$-transferase (GST)-fused leucotoxins, after being electroporated as recommended (Pharmacia, Uppsala, Sweden). pGEX 6P-1 (Pharmacia) was the expression vector for leucotoxins and their mutants.

\subsection{Cloning and expression of LukF-PV in E. coli}

Proteins were expressed in $E$. coli through the gene fusion system (GST, Pharmacia). Briefly, DNA sequences corresponding to secreted proteins and containing the putative $3^{\prime}$ inverted repeats were amplified via dedicated oligonucleotides containing EcoRI restriction sites at their 5'-end. After EcoRI restriction, amplified DNA fragments 
were cloned into pGEX-6P-1. The right oriented recombinant plasmids were used as templates for site-directed mutagenesis, achieved by using the Quick Change Mutagenesis kit (Stratagene). Briefly, reactions were performed in the presence of $5 \mathrm{ng}$ of template $(5.8 \mathrm{~kb}), 0.25$ $\mathrm{mM}$ dNTP, $0.4 \mathrm{nM}$ of each oligonucleotide and $5 \mathrm{U}$ of $P f u$ Turbo DNA polymerase in $50 \mu \mathrm{l}$. Temperatures of hybridisation, elongation and denaturation were $50^{\circ} \mathrm{C}, 68^{\circ} \mathrm{C}$ and $95^{\circ} \mathrm{C}$ during $30 \mathrm{~s}, 3 \min 30 \mathrm{~s}$ and $1 \mathrm{~min}$, respectively. Initial templates were eliminated with a 80 min $D p n I$ restriction and $2.5 \mu \mathrm{l}$ aliquots were used to transform $80 \mu \mathrm{l}$ of XL1 Blue Supercompetent cells as recommended (Stratagene). Mutated genes were sequenced [20] before to be electroporated at $1.8 \mathrm{kV}$, $200 \Omega, 25 \mu \mathrm{F}$ in $80 \mu \mathrm{l}$ of $E$. coli BL 21 previously stored at 5.0 $\mathrm{OD}_{600 \mathrm{~nm}}$ units in $0.1 \mathrm{mM}$ HEPES, pH 7.0. Transformed bacteria were treated and plated as recommended (GST, Pharmacia).

\subsection{Purification of E. coli recombinant leucotoxin components}

Recombinant $E$. coli BL 21 mutated clones were inoculated from a starter into $2 \times 400 \mathrm{ml}$ of $2 \times$ TY filled in 21 Erlenmeyer flasks, and cultivated for $6 \mathrm{~h}$ before overnight induction of the GST fused protein with $0.2 \mathrm{mM}$ IPTG. Bacteria were harvested by centrifugation and concentrated as a $30 \%(\mathrm{w} / \mathrm{v})$ suspension into $30 \mathrm{mM}$ Na-phosphate, $150 \mathrm{mM} \mathrm{NaCl}, 1 \mathrm{mM}$ EDTA, $\mathrm{pH}$ 7.0. Then, bacteria were sheared at $9000 \mathrm{~Pa} / \mathrm{si}$ with a French Pressure Cell Press (SLM Instruments-Bioritech, Joinville sur Juine, France). Cell debris were discarded by a 30 min centrifugation at $30000 \times g$ at $6^{\circ} \mathrm{C}$ and GST activity of the lysate was measured at $340 \mathrm{~nm}$ as recommended. A volume of lysate corresponding to $4 \mathrm{mg}$ of titrated GST was applied on a glutathione Sepharose 4B column (Pharmacia) equilibrated with $60 \mathrm{mM}$ Tris-HCl, $\mathrm{pH}$ 8.0. The fused protein was eluted in the same buffer containing 30 $\mathrm{mM}$ glutathione, and further digested overnight by $5 \mathrm{U} / \mathrm{mg}$ of PreScission protease (Pharmacia). The leucotoxin components were purified through a $1.35 \mathrm{M}$ to $0.45 \mathrm{M}\left(\mathrm{NH}_{4}\right)_{2} \mathrm{SO}_{4}$ gradient applied on an AlkylSuperose fast performance liquid chromatography (FPLC, Pharmacia), which eluted at $0.75 \mathrm{M}\left(\mathrm{NH}_{4}\right)_{2} \mathrm{SO}_{4}$. The pre-purified $\mathrm{F}$ components were dialysed against $30 \mathrm{mM}$ MES, $\mathrm{pH} 6.3$ and purified to homogeneity by a MonoS FPLC through a 0 to $150 \mathrm{mM} \mathrm{NaCl}$ gradient, with elution around $90 \mathrm{mM} \mathrm{NaCl}$. Purified proteins were controlled by SDS-PAGE and radial gel immunoprecipitation and stored at $\mathrm{OD}_{280 \mathrm{~nm}}=1.0$ at $-80^{\circ} \mathrm{C}$. None of the proteins discussed below presented apparent variations in their physicochemical properties.

\subsection{Labelled proteins}

LukF-PV Ser27Cys, a functional cysteine mutated protein was labelled with fluorescein 5-maleimide (Molecular Probes, Leiden, The Netherlands) at a 5-fold excess for $30 \mathrm{~min}$ at room temperature as a $10 \mu \mathrm{M}$ protein solution in $50 \mathrm{mM}$ Na-phosphate, $0.15 \mathrm{M} \mathrm{NaCl}, 1 \mathrm{mM}$ EDTA $\mathrm{Na}_{2}, \mathrm{pH}$ 7.0. The coupling reaction was stopped by the addition of $10 \mathrm{mM} \beta$-mercaptoethanol. The mixture was then desalted and the coupling yield was determined by the ratio of the determined concentration of fluorescein $\left(\varepsilon_{490 \mathrm{~nm}}=81900 \mathrm{~cm}^{-1} \mathrm{~mol}^{-1}\right)$ and that of the protein determined by the Bradford titration (Bio-Rad, Ivry sur Seine, France)

LukF-PV Gly130Cys and LukF-PV Gly131Cys, at $40 \mu \mathrm{M}$ in $0.2 \mathrm{M}$ Na-phosphate, $1 \mathrm{mM} \beta$-mercaptoethanol pH 8.0 were labelled with 15 mM AMSD [4 acetamido-4' maleimidyl stilbene 2,2' disulfonic acid, disodium salt dissolved at $0.1 \mathrm{M}$ in $\mathrm{H}_{2} \mathrm{O}, \varepsilon_{320 \mathrm{~nm}}=29000 \mathrm{M}^{-1} \cdot \mathrm{cm}^{-1}$ (Molecular Probes)] in dark at room temperature for $30 \mathrm{~min}$. Reaction was stopped by adding $30 \mathrm{mM} \beta$-mercaptoethanol for $30 \mathrm{~min}$ in the dark. Protein solutions (Gly130Cys* and Gly131Cys* in the text) were then centrifuged for $10 \mathrm{~min}$ at $8000 \times g$ at $4^{\circ} \mathrm{C}$, and peptides purified onto a FPLC MonoS chromatography using a $\mathrm{NaCl}$ gradient ranging from 0 to $700 \mathrm{mM} \mathrm{NaCl}$ in $50 \mathrm{mM} \mathrm{NaH} \mathrm{PO}_{4} \mathrm{pH} 7.0$, stored in dark at $4^{\circ} \mathrm{C}$ at $\mathrm{OD}_{280 \mathrm{~nm}}=1.0$.

\subsection{Human polymorphonuclear cells (PMNs) and flow cytometry measurements}

Thirty mililitres of buffy coats from healthy donors diluted with 10 $\mathrm{ml}$ of $0.9 \%(\mathrm{w} / \mathrm{v}) \mathrm{NaCl}$ were added to $12 \mathrm{ml}$ of J-Prep solution (TechGen) and human PMNs were purified as previously reported [6]. Cells were suspended and adjusted to $2 \times 10^{6}$ cells $/ \mathrm{ml}$ in $140 \mathrm{mM} \mathrm{NaCl}$, $5 \mathrm{mM} \mathrm{KCl}, 10 \mathrm{mM}$ glucose, $0.1 \mathrm{mM}$ ethylene glycol-bis(beta-aminoethyl ether) $N, N, N^{\prime}, N^{\prime}$-tetraacetic acid, $10 \mathrm{mM}$ HEPES, $3 \mathrm{mM}$ Trisbase $(\mathrm{pH} 7.3)$. Flow cytometry experiments were made with $5 \times 10^{5}$ cells $/ \mathrm{ml}$ loaded in $5 \mu \mathrm{M}$ Fluo-4 solution (Molecular Probes, Eugene, OR, USA) during $1 \mathrm{~h}$ at $37^{\circ} \mathrm{C}$ in the latter buffer, then washed and resuspended in the presence of $1.1 \mathrm{mM} \mathrm{Ca}^{2+}$ for the evaluation of $\mathrm{Ca}^{2+}$ entry. Each component constituting the leucotoxins tested was generally added at $1 \mathrm{nM}$. Flow cytometry measurements from 3000 gated leucocytes were performed as previously described $[12,13]$ by using a FacSort cytometer (Becton-Dickinson, Le Pont de Claix, France). Fluo-4 fluorescence due to the calcium penetration was recorded from the fluorescence light $1\left(\mathrm{FL} 1: \lambda_{\mathrm{em}}=530 \mathrm{~nm}\right)$, every $30 \mathrm{~s}$ during $45 \mathrm{~min}$. After subtraction of basic fluorescence, the results were compared to the maximum fluorescence of controls indicating the potentiality of the different purified leucotoxins to open $\mathrm{Ca}^{2+}$ channels. The fluorescence light 3 (FL3: $\lambda_{\mathrm{em}}=650 \mathrm{~nm}$ ) was used to record ethidium fluorescence, applied at $25 \mathrm{nM}$ together with the leucotoxins. This fluorescence increased after the molecule entered the cell membrane by the pores formed because of combination with nucleic acids. Means of four series of data, at least, obtained from PMNs of four different donors were calculated by Lysis 2TM software (Becton-Dickinson, France). Results were expressed as mean fluorescence percentages from controls. Standard deviations were mentioned in Table 1.

By using a full functional fluorescein-labelled LukF-PV Ser27Cys, binding abilities of LukF-PV and inactive mutants combined with $3 \mathrm{nM}$ LukS-PV were determined by competition experiments in the absence of extracellular calcium using a concentration of $20 \mathrm{nM}$ of the labelled LukF-PV Ser27Cys, and variable concentrations of $1,5,10$, 20, 50, 100 and $200 \mathrm{nM}$ of the mutated proteins. The residual fluorescences at the cell surface were gated during $50 \mathrm{~min}$ after the application of the protein couples LukS-PV+X to minimise the influence of lysed cells in the data. Apparent inhibition constants $\left(K_{\mathrm{i} \text { app }}\right)$ were deduced by projection to abscissa of the $50 \%$ mean fluorescence values (IC50), with the following equation:

$K_{\text {i app }}=\mathrm{IC}_{50} / 1+[\mathrm{F}] / K_{\mathrm{d} \mathrm{F}}$

where $[\mathrm{F}]$ is the concentration of the fluorescent LukF-PV Ser27Cys and $K_{\mathrm{dF}}=3 \mathrm{nM}$ (D.A. Colin, personal communication).

Pore diameters created by leucotoxins were assessed by an evaluation of the FSC of treated cells $\left(5 \times 10^{5}\right.$ cells $\left./ \mathrm{ml}\right)$ with $1 \mathrm{nM}$ of LukS$\mathrm{PV}$ and $20 \mathrm{nM}$ of F component and $30 \mathrm{mM}$ of polyethylene glycol (PEG) beads of different radius $(0.94,1.2,1.22$ and $1.44 \mathrm{~nm})$. Forward light scatter values were collected at $0,10,20$ and $30 \mathrm{~min}$ after toxin application.

\subsection{IL-8 titration}

Equimolar amounts $(1 \mathrm{nM})$ of PVL or LukS-PV/LukF-PV G130D, or LukS-PV/LukF-PV $\Delta$ Ser125-Leu128 were applied for $20 \mathrm{~min}$ at room temperature to $0.5 \mathrm{ml}$ of the buffer cited in Section $2.5,1.1$ $\mathrm{mM} \mathrm{CaCl} 2$ containing $5 \times 10^{5}$ cells $/ \mathrm{ml}$. After treatment, washed cells corresponding to half the volume of the assays was treated for lysis with $0.2 \%(\mathrm{v} / \mathrm{v})$ Triton X-100 (Boehringer). Cells or cell debris were immediately pelleted at $4{ }^{\circ} \mathrm{C}$ and $50 \mu \mathrm{l}$ of the supernatant were subjected to IL-8 titration. IL-8 from secretion fluids or cell lysates was titrated with an ELISA kit used as recommended by the manufacturer (Endogen-Interchim, Montluçon, France).

\subsection{Activity of modified LukF-PV in rabbit skin}

Shaved rabbits of at least $2.5 \mathrm{~kg}$ were injected intradermally with 50 $\mu 1$ of sterile $9.55 \%$ o (w/v) PBS Dulbeccos solution with equal amounts (300, 1000, 3000 or $10000 \mathrm{ng}$ ) of LukS-PV and native or mutated LukF-PV. Macroscopic clinical observations were recorded at 24 and $48 \mathrm{~h}$ after injection of toxins. Five reaction levels [6] corresponding to the intensity of the inflammatory reaction were attributed: level 0 was the normal skin, level 1 showed a red inflammatory reaction (diameter $=10-15 \mathrm{~mm}$ ) without abscess formation, level 2 showed a hot, red papule with relief (diameter $=15-20 \mathrm{~mm}, 5 \mathrm{~mm}$ high), level 3 showed a more intense abscess (diameter $=20-30 \mathrm{~mm}, 10 \mathrm{~mm}$ high) becoming blue and oedematous, level 4 still progressed in intensity (diameter $\geq 30 \mathrm{~mm}, 10-15 \mathrm{~mm}$ high) with white pus collection surrounded by blue oedema, level 5 showed a lesion in progress with a central depression and pus sweating.

\section{Results}

\section{1. $\mathrm{Ca}^{2+}$ and ethidium entries induced by the mutated proteins}

Substitutions of LukF-PV by different residues were generated at two glycine positions: Gly130Asp, Gly130Cys, 
Table 1

Compiled values for each mutated LukF-PV protein combined with LukS-PV

\begin{tabular}{|c|c|c|c|c|c|c|c|c|c|}
\hline & \multicolumn{2}{|c|}{$\mathrm{Ca}^{2+}$ entry } & \multicolumn{2}{|c|}{ Ethidium entry } & \multirow{2}{*}{$\begin{array}{l}K_{\mathrm{iapp}} \\
(\mathrm{nM})\end{array}$} & \multirow{2}{*}{$\begin{array}{l}\text { Pore radius } \\
(\mathrm{nm})\end{array}$} & \multicolumn{2}{|l|}{ IL-8 } & \multirow{2}{*}{$\begin{array}{l}\text { Dermo. dose } \\
\text { (ng toxin) }\end{array}$} \\
\hline & Lag-T $^{a}$ & $\frac{F * \times 100}{F * L u k F-P V}$ & Lag-T ${ }^{\mathrm{a}}$ & $\frac{F * \times 100}{F * L u k F-P V}$ & & & Sec. ${ }^{b}$ & Cell. $^{b}$ & \\
\hline LukF-PV & $<1.5$ & 100 & 5 & 100 & 3.2 & 1.2 & $102 \pm 8$ & $316 \pm 22$ & 2000 \\
\hline G130D & $<1.5$ & $88 \pm 7.4$ & 30 & $70 \pm 8.2$ & 3.9 & 1.2 & $106 \pm 8$ & $340 \pm 16$ & $>20000$ \\
\hline G130W & $<2.5$ & $95 \pm 2$ & 10 & $97 \pm 1.6$ & nd & nd & $98 \pm 6$ & $286 \pm 16$ & 2000 \\
\hline G130K & $<2.5$ & $98 \pm 1.9$ & 10 & $91 \pm 1.9$ & nd & nd & nd & nd & nd \\
\hline G130C & $<2.5$ & $95 \pm 0.8$ & 5 & $97 \pm 1.8$ & nd & nd & $102 \pm 6$ & $288 \pm 18$ & 2000 \\
\hline G131C & $<2.5$ & $94 \pm 0.6$ & 10 & $96 \pm 0.6$ & nd & nd & nd & nd & nd \\
\hline G131D & $<2.5$ & $94 \pm 2$ & 20 & $91 \pm 2.7$ & 2.8 & 1.2 & nd & nd & 6000 \\
\hline G131W & $<2.5$ & $88 \pm 2.1$ & 20 & $91 \pm 2.2$ & 3.4 & nd & $84 \pm 8$ & $290 \pm 18$ & 6000 \\
\hline$\Delta \mathrm{S} 125-\mathrm{L} 128$ & $<2.5$ & $89 \pm 6.7$ & 30 & $89 \pm 9.1$ & 1.17 & 1.2 & $110 \pm 6$ & $286 \pm 14$ & 20000 \\
\hline$\Delta \mathrm{L} 128-\mathrm{S} 135$ & - & 9 & - & $6 \pm 2$ & $>70$ & - & nd & nd & nd \\
\hline$\Delta \mathrm{I} 124-\mathrm{S} 129$ & - & 9 & - & $7 \pm 2$ & 6.2 & - & nd & nd & $>20000$ \\
\hline G130C* & 5 & $38 \pm 9.3$ & 30 & $84 \pm 0.9$ & 14.3 & 1.2 & $45 \pm 6$ & $408 \pm 8$ & 20000 \\
\hline G131C* & 5 & $48 \pm 8.4$ & 35 & $84 \pm 8.6$ & 13 & nd & nd & nd & nd \\
\hline
\end{tabular}

Lag times (Lag-T), fluorescence maxima $\left(\mathrm{F}^{*}\right)$ expressed as percentages from controls for calcium (revealed by Fluo-4 fluorescence) and ethidium entries; apparent $K_{\mathrm{i}}$, binding constants in competition with Luk-PV S27C-fluorescein; pore radius; ng of secreted (Sec.) and cellular (Cell.)

IL-8 induced by a 20 min treatment of $2 \times 10^{5}$ human PMNs/200 $\mu$ l with $1 \mathrm{nM}$ of leucotoxins; and minimal doses necessary to obtain an acute dermonecrosis (Dermo. dose) in the rabbit skin.

${ }^{a}$ Representative values of four different experiments.

${ }^{b}$ Mean \pm S.D. of four different experiments.

Gly130Lys, Gly130Trp, Gly131Asp, Gly131Cys and Gly131Trp. The two cysteine mutants were further labelled with AMSD, a $18 \AA$ long compound with a rigid structure except at the label extremity. Deletions in the stem domain were also engineered (Luk-PV $\Delta$ Ile124-Ser129, $\Delta$ Ser125Leu128, $\Delta$ Leu128-Ser135) in order to reduce the length of the transmembrane moiety of the toxin. Such a configuration might favour the partial obturation of the cytoplasmic edge of the pore by membrane phospholipids.

Table 1 and Fig. 1 show the biological activities on human PMNs of all modified PVL made of the native LukS-PV and of the mutated proteins. Table 1 gives lag times (Lag-T) for both $\mathrm{Ca}^{2+}$ and ethidium entries as well as the ratio of the maximal fluorescence of the modified leucotoxins compared to the native PVL. Fig. 1 gives representative curves of $\mathrm{Ca}^{2+}$ and ethidium entries representative for several mutated leucotoxins. Four groups of mutated proteins were differentiated according to their biological activities:

1. LukF-PV Gly130Cys, Gly130Lys, Gly130Trp, and Gly131Cys were as active as the native toxin for both the $\mathrm{Ca}^{2+}$ and ethidium entries (Table 1 and Fig. 1C,F).

2. On the contrary, two deletion mutants LukF-PV $\Delta$ Leu128Ser135 and $\Delta$ Ile124-Ser129 displayed no activity (Table 1 and Fig. 1A,D).

3. Two other modified proteins, LukF-PV Gly130Cys* and Gly131Cys*, presented concerted decreases in the two biological activities. These decreases were significant since the kinetic effects when using $1 \mathrm{nM}$ of these mutated proteins were similar to those obtained with only $0.05 \mathrm{nM}$ of native PVL (Fig. 1C,F). The lag times for the entries of $\mathrm{Ca}^{2+}$ and ethidium (Table 1) amounted 5 and $30 \mathrm{~min}$ compared to 1.5 and $5 \mathrm{~min}$ for native PVL $(1 \mathrm{nM})$, respectively. The maximal fluorescence intensity for the $\mathrm{Ca}^{2+}$ induction and for ethidium entry represented $30-40 \%$ and $85 \%$ of that induced using $1 \mathrm{nM}$ of PVL, respectively. When the concentration of the mutated leucotoxins was increased to 10
$\mathrm{nM}$, both activities were larger, but did not reach those measured with $1 \mathrm{nM}$ PVL (Fig. 1C,F). Therefore, these two mutated and chemically modified proteins were at least 10-fold less active than PVL.

4. When combined with LukS-PV, four mutated proteins LukF-PV $\quad \Delta$ Ser125-Leu128, LukF-PV Gly131Asp, Gly131Trp and Gly130Asp showed differences in $\mathrm{Ca}^{2+}$ induction and pore-formation. LukF-PV $\Delta$ Ser125-Leu128 was inducing $\mathrm{Ca}^{2+}$ entry at a level comprised between those observed with $1 \mathrm{nM}$ and $0.1 \mathrm{nM}$ of PVL (Fig. 1A). Lag times for $\mathrm{Ca}^{2+}$ and ethidium were $<2.5$ and $30 \mathrm{~min}$, respectively, whereas maximal fluorescences reached $89 \%$ of that of PVL (Table 1 and Fig. 1A,D). $\mathrm{Ca}^{2+}$ entry using $10 \mathrm{nM}$ of this modified leucotoxin was larger than with $1 \mathrm{nM}$ PVL, whereas ethidium entry remained similar to that observed using $0.1 \mathrm{nM}$ LukF-PV (Fig. 1D). It was assumed that, for LukS-PV+LukF-PV $\Delta$ Ser125-Leu128, ethidium penetration was about 10 -fold more inhibited than $\mathrm{Ca}^{2+}$ induction. Similar results were obtained for LukF-PV Gly131Asp, and Gly131Trp (Table 1 and Fig. $1 \mathrm{~B}, \mathrm{E})$, except that the corresponding leucotoxins fully induced $\mathrm{Ca}^{2+}$ entry, while ethidium entry was delayed with a lag time of $20 \mathrm{~min}$ and corresponded to a 10 -fold decrease of activity. These discrepancies were larger with LukF-PV Gly130Asp. The latter induced $\mathrm{Ca}^{2+}$ entry in human PMNs in the same way as LukF-PV but ethidium penetration was considerably decreased. The lag time was around $30 \mathrm{~min}$ and a maximum of $70 \%$ of fluorescence intensity was only reached after $120 \mathrm{~min}$, while this value was obtained after only 60 min with PVL. This mutated protein was assumed to be at least 20-fold less functional with respect to pore formation than PVL, although $\mathrm{Ca}^{2+}$ induction appeared fully conserved. Morphologic (side light scatter) and granularity (forward light scatter) parameters recorded during flow cytometry for these mutants accounted for a diminished lytic property of this mutated toxin compared to PVL. 


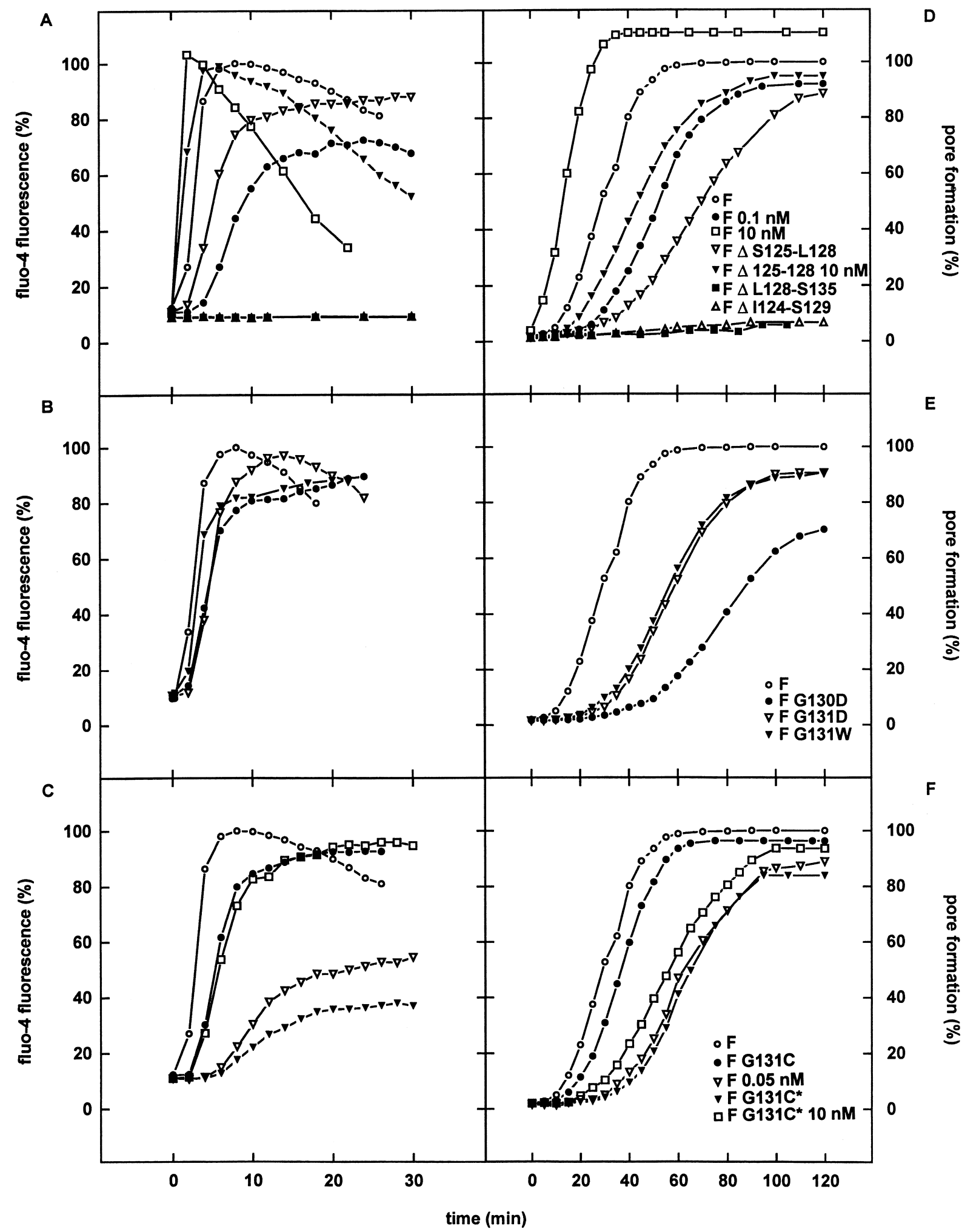

Fig. 1. Evaluation by flow cytometry of the $\mathrm{Ca}^{2+}$ penetration (A, B and C) and of the pore-forming abilities (D, E and F) according to time, of LukS-PV+LukF-PV or modified proteins (indicated horizontally), on human PMNs. Curves were calculated as means of four different experiments on different donors and expressed as percentages of maximum of fluorescence. Standard deviations are mentioned in Table 1 . Ca ${ }^{2+}$ entry (left) was recorded in the presence of $1.1 \mathrm{mM}$ extracellular $\mathrm{CaCl}_{2}$ from Fluo-4-charged cells. Pore-formation indicated by ethidium fluorescence after its combination with nucleic acids was achieved in the absence of extracellular calcium. The decrease of Fluo-4 fluorescence was assumed as a natural loss of the probe and/or a loss due to cell lysis. 

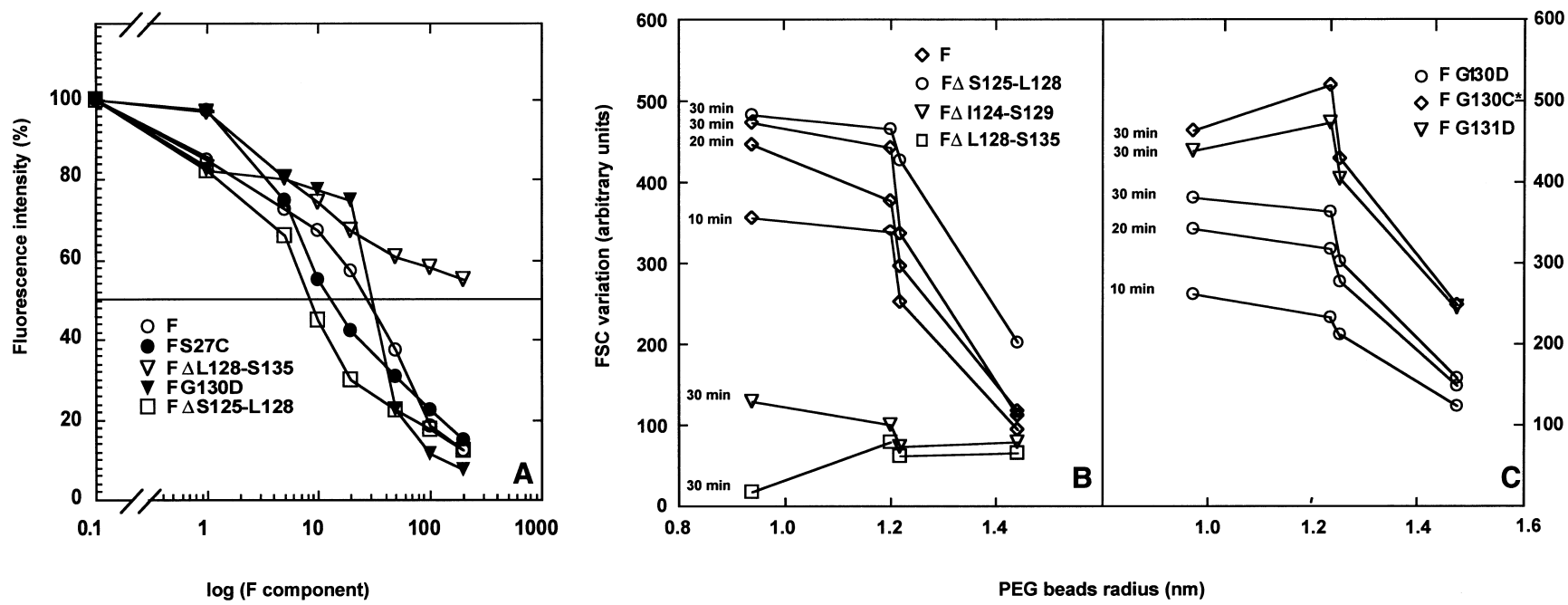

Fig. 2. A: Binding competition experiments to LukS-PV-PMNs membranes complexes between the fluorescein-labelled LukF-PV Ser27Cys and LukF-PV (F), LukF-PV Ser27Cys (FS27C), LukF-PV Gly130Asp (FG130D), LukF-PV $\Delta$ Ser125-Leu128 (F $\Delta$ Ser125-Leu128), LukF-PV $\Delta$ Leu128-Ser135 (F $\Delta$ Leu128-Ser135), according to percentages of fluorescence intensities and concentration of $F$ components. B and C: Probing the diameter of pores with calibrated PEG molecules, formed by modified leucotoxins: LukS-PV combined with LukF-PV (F), LukF-PV Gly130Cys* (FG130C*), LukF-PV Gly130Asp (FG130D), LukF-PV Gly131Asp (FG131D), LukF-PV $\Delta$ Ser125-Leu128 (F $\Delta$ Ser125-Leu128), LukF-PV $\Delta$ Ile124-Ser129 (F $\Delta$ Ile124-Ser129), LukF-PV $\Delta$ Leu128-Ser135 (F $\Delta$ Leu128-Ser135). Forward light scatter variations (FSC) were recorded at 10, 20 and 30 min following toxin application.

\subsection{Binding of the mutated LukF-PV proteins}

To determine the binding properties of mutated LukF-PV on the LukS-PV-membrane complexes, competition experiments with the fully functional fluorescein-labeled LukF-PV Ser27Cys were performed. As shown in Table 1 and Fig. 2A, the most interesting proteins (e.g. Gly130Asp, Gly131Asp, Gly131Trp and $\Delta$ Ser125-Leu128) displayed $K_{\mathrm{i} \text { app }}$ between 1.2 and $3.9 \mathrm{nM}$. Despite the lack of biological activity, LukF-PV $\Delta$ Ile124-Ser129 significantly binds to the LukS-PVmembrane complexes with $K_{\mathrm{i} \text { app }}=6.2$ nM. LukF-PV Gly131Cys* and Gly130Cys* binds less efficiently with $K_{\mathrm{i} \text { app }}=13-14 \mathrm{nM}$. The LukF-PV $\Delta$ Leu128-Ser135 seemed devoid of binding to those complexes.

\subsection{Pore diameters created by modified leucotoxins}

The intrinsic diameter of pores formed by native and modified leucotoxins was assessed using flow cytometry by a quantitative evaluation of the modification of the cell granularity which follows the application of calibrated polyethylene glycol beads. Some of the protein couples tested, PVL, LukSPV+LukF-PV $\Delta$ Ser125-Leu128 (Fig. 2B) or for LukSPV+LukF-PV Gly130Cys* or Gly131Asp (Fig. 2C), or LukS-PV+LukF-PV Gly131Trp or Gly131Cys* (data not shown) formed pores and excluded PEG beads of a radius greater than $1.2 \mathrm{~nm}$. However, it appeared that cell disorders (forward light scatter) induced by the couple LukS-PV+LukFPV Gly130Asp (Fig. 2C) did not occur as fast as with PVL. Finally, permeability was not significant for modified leucotoxins composed with LukF-PV $\Delta$ Leu128-Ser135 or $\Delta$ Ile124Ser129 (Fig. 2B), even $30 \mathrm{~min}$ after protein application.

\subsection{IL-8 secretion induced by modified leucotoxins}

Secretion of IL-8 from human PMNs treated by leucotoxins was evidenced by titration of the cytokine (Table 1). PVL $1 \mathrm{nM}$ induced a significant secretion of IL-8 $(102 \pm 8 \mathrm{ng} / \mathrm{ml})$ but the total cell content of IL-8 remained larger $(316 \pm 22 \mathrm{ng} /$ $\mathrm{ml})$. Similar results were obtained using a series of modified leucotoxins such as LukF-PV Gly130Asp, Gly130Trp, Gly130Cys, Gly131Trp, $\Delta$ Ser125-Leu128. LukF-PV Gly130Cys* which displayed a decreased $\mathrm{Ca}^{2+}$ induction and ethidium entry did not promote secretion of IL-8 $(45 \pm 6 \mathrm{ng} / \mathrm{ml})$. The sum of secreted $(15 \pm 2 \mathrm{ng} / \mathrm{ml})$ and total IL- 8 content for non-treated cells $(472 \pm 21 \mathrm{ng} / \mathrm{ml})$ equals that of PVL-treated cells. Increase of toxin concentration to $5 \mathrm{nM}$ did not influence amounts of total IL-8. Treatment of human PMNs by PVL for $80 \mathrm{~min}$ led to the secretion of IL- 8 at $422 \pm 31 \mathrm{ng} / \mathrm{ml}$ and to a cell content of $186 \pm 12 \mathrm{ng} / \mathrm{ml}$, whereas LukS-PV+LukF-PV Gly130Asp led to only $136 \pm 13 \mathrm{ng} / \mathrm{ml}$ of secreted IL-8 and to a cell content of $396 \pm 23 \mathrm{ng} / \mathrm{ml}$.

\subsection{Inflammatory reaction promoted by modified leucotoxins}

To determine whether host inflammatory reaction can be attributed to the activation function of leucotoxins, PVL and some modified leucotoxins were compared for their ability to induce dermonecrosis in rabbit skin (Table 1). When injected in the rabbit skin, dermonecrosis with pus collection (level 4) was clearly induced with $2000 \mathrm{ng}$ of PVL (1000 ng of each component), or LukS-PV+LukF-PV Gly130Trp, or + Gly130Cys within $48 \mathrm{~h}$, whereas similar levels of dermonecrosis were obtained with $6000 \mathrm{ng}$ of LukS-PV+LukF-PV G131D, or + G131W. Comparable lesions were obtained with $20000 \mathrm{ng}$ of LukS-PV+LukF-PV $\Delta$ Ser125-Leu128, or + Gly130Asp.

Doses of $20000 \mathrm{ng}$ of LukS-PV+LukF-PV $\Delta$ Ile124-Ser129, or +Gly130Cys* only induced a dermanecrotic reaction at level 2. Therefore, it appeared that leucotoxins with decreased pore-formation ability were at least 10 -fold less virulent than PVL on the rabbit skin.

\section{Discussion}

In this study, we provided evidence that mutant proteins of LukF-PV enabled the discoupling of the $\mathrm{Ca}^{2+}$ induction and of the pore-formation activities of a staphylococcal bi-compo- 

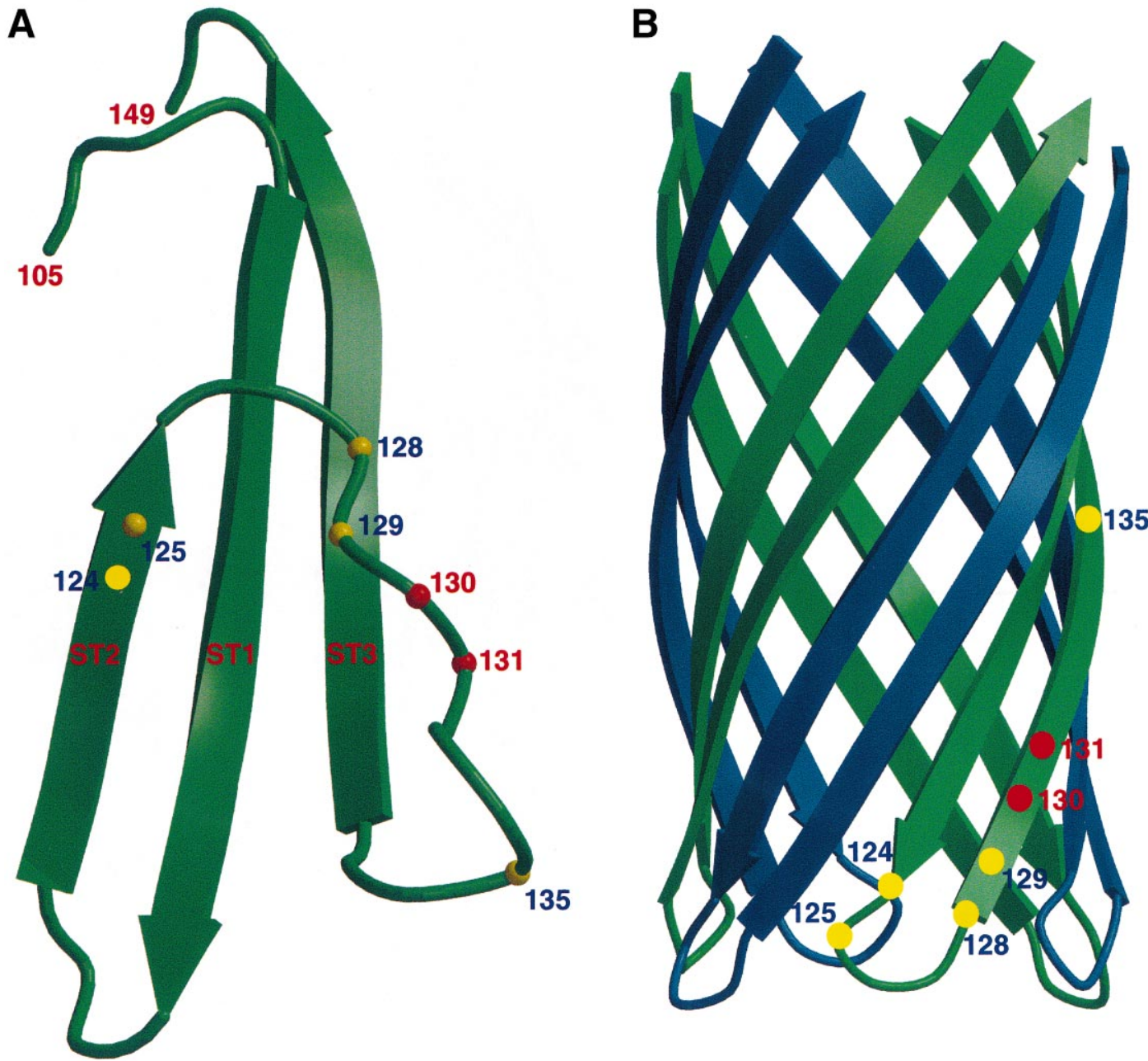

Fig. 3. Ribbon representation of the stem domain (A) in the water-soluble monomeric LukF-PV and (B) in a molecular transmembrane pore of PVL [15]. The LukF-PV and LukS-PV components are shown in green and blue, respectively. Positions of the residues that were either substituted or which line deleted regions are shown as red and yellow dots, respectively. The figure was produced by using the programs Molscript [9], and Raster 3-D [11].

nent leucotoxin. Pore-formation was reduced or cancelled by mutagenesis in the stem domain [15]. Residues Gly-130 and Gly-131 in LukF-PV (Fig. 3A), which were replaced by different amino acids, correspond to Ile-132 and Gly-133 of the $\alpha$ toxin, located in the outer and the inner leaflet of the heptameric pore $[18,21,22]$, respectively. According to the hexamer model of PVL [15], and to the alignment with the $\alpha$-toxin sequence [4,5], Gly-130 and Gly-131 would have homologous locations. Three deletion mutants were engineered. Two of them, LukF-PV $\Delta$ Ser125-Leu128 and $\Delta$ Ile124-Ser129 map in the ST2 $\beta$-sheet [15] and in the following loop of the monomeric protein, respectively. These deletions also map at the bottom of the stem in the pore-forming oligomer, $\Delta$ Leu128Ser135 removed half of the cross-over loop between strands ST2 and ST3 in the monomer, and part of a $\beta$-sheet in the pore-forming stem ([15], see Fig. 3A,B). This deletion led to a protein which did not bind significantly to the membraneLukS-PV complex. Residues 128-135 are solvent-exposed in the monomeric structure [15] and should contribute to proper fold of the stem domain and to binding efficiency of the hydrosoluble LukF-PV.

When combined with LukS-PV, LukF-PV $\Delta$ Ile124-Ser129 and Gly130Cys* and Gly131Cys* showed a drastic decrease in biological activities. LukF-PV $\Delta$ Ile124-Ser129 which binds to the membrane-LukS-PV complex but does not activate cells and generate pore-formation, might prevent insertion of the pre-pore or promote incorrect structuration of the $\beta$-barrel. Labelling with AMSD resulted in disorganisation of every step of the pore-construction independently of the inner or outer location of the substituted residue. AMSD which is a highly solvated molecule might reorient inside the lumen of the pores inducing local and charged hindrance.

Finally, one deletion, LukF-PV $\Delta$ Ser125-Leu128, and three substitutions, Gly130Asp, Gly131Asp and Gly131Trp led to modified leucotoxins for which pore-formation and $\mathrm{Ca}^{2+}$ entry were discoupled in various extents. The major effect was observed with LukS-PV+LukFPV Gly130Asp. Polar incompatibility between the latter mutant and the membrane seemed to disturb only local topology since IL-8 secretion and permeability to PEG were conserved. Substitutions of LukF-PV Gly-131 by Asp or Trp led to similar results. The carboxylate or the indole ring might interact with either the quaternary amine or the hydrophobic part of ethidium, respectively. The $\Delta$ Ser125-Leu128 produced a modified LukF-PV able to bind the LukS-PV-membrane complex and to create pores with a low sensitivity to ethidium. According to the model of hexameric PVL ([15], Fig. 3B), such a 
deletion shortens the edge of the stem domain, and likely disturbs the intracellular part of the $\beta$-barrel, though allowing the traffic of solvated

PEG molecules.

The leucotoxins formed by LukS-PV+LukF-PV Gly130Asp, +Gly130Cys, +Gly130Trp, +Gly131Trp, or $+\Delta$ Ser125-Leu128 that lacked pore-formation induced a similar secretion of IL-8 as PVL, supporting that leucotoxins have cell-activation properties [8]. The less $\mathrm{Ca}^{2+}$ inducer, LukS-PV+LukF-PV Gly130Cys*, was observed to induce a less efficient IL-8 secretion.

Furthermore, when challenged in a rabbit dermonecrosis experimental model [3,6], LukF-PV Gly130Asp and $\Delta$ Ser125-Leu128 were less inflammatory when combined with LukS-PV. It suggests that pore-formation is an essential function for the virulence of PVL. In view of the delay because of delay between the two activating and the lytic functions, one may hypothesise the first cited function favours potential of cells, while cell lysis is required to amplify inflammation. Such a process may also be essential to provide nutrients for the bacterial growth and spreading, whereas cell debris generated by the lytic activity may complicate the general immune response. This study showed that it may be possible to discouple the cell-activating and the lytic properties of PVL, and may be some pore-forming toxins. The structural basis of these two functions should be assessed to define their respective roles in virulence.

Acknowledgements: We thank D. Keller and R. Girardot for skillful technical assistance and A. Gravet for helpful discussion. This work was supported by Grant EA-1318 from the 'Direction de la Recherche et des Etudes Doctorales (DRED)'.

\section{References}

[1] Colin, D.A., Mazurier, I., Sire, S. and Finck-Barbançon, V. (1994) Infect. Immun. 62, 3184-3188.

[2] Couppié, P., Cribier, B., Prévost, G., Grosshans, E. and Piémont, Y. (1994) Arch. Dermatol. 130, 1208-1209.
[3] Cribier, B., Prévost, G., Couppié, P., Finck, B.V., Grosshans, E. and Piémont, Y. (1992) Dermatology 185, 175-180.

[4] Gouaux, J.E. (1997) Curr. Opin. Struct. Biol. 7, 566-573.

[5] Gouaux, J.E., Hobaugh, M. and Song, L. (1998) Protein Sci. 6, 2631-2635.

[6] Gravet, A., Colin, D.A., Keller, D., Girardot, R., Monteil, H. and Prévost, G. (1998) FEBS Lett. 436, 202-208.

[7] König, B., Köller, M., Prévost, G., Piémont, Y., Alouf, J.E., Schreiner, A. and König, W. (1994) Infect. Immun. 62, 48314837.

[8] König, B., Prévost, G., Piémont, Y. and König, W. (1995) J. Infect. Dis. 171, 607-613.

[9] Kranlio, P.J. (1991) J. Appl. Crystallogr. 24, 946-950.

[10] Lesieur, C., Vecsey-Semjen, B., Abrami, L., Fivaz, M. and van der Goot, F.G. (1997) Mol. Membr. Biol. 14, 45-64.

[11] Merritt, E.A. and Murphy, M.E.P. (1994) Acta Crystallogr. D 50, 869-873.

[12] Meunier, O., Falkenrodt, A., Monteil, H. and Colin, D.A. (1995) Cytometry 21, 241-247.

[13] Meunier, O. et al. (1997) Biochim. Biophys. Acta 1326, 275286.

[14] Olson, R., Nariya, H., Yokota, K., Kamio, Y. and Gouaux, E. (1999) Nat. Struct. Biol. 6, 134-140.

[15] Pédelacq, J.D., Maveyraud, L. and Prévost, G. et al. (1999) Structure 7, 277-287.

[16] Prévost, G., Cribier, B., Couppié, P., Petiau, P., Supersac, G., Finck-Barbançon, V., Monteil, H. and Piémont, Y. (1995) Infect. Immun. 63, 4121-4129.

[17] Prévost, G. (1999) in: The Comprehensive Sourcebook of Bacterial Toxins (Alouf, J.E. and Freer, J.H., Eds.), pp. 402-418, Academic Press, London.

[18] Song, L., Hobaugh, M.R., Shustak, C., Cheley, S., Bayley, H. and Gouaux, J.E. (1996) Science 274, 1859-1866.

[19] Staali, L., Monteil, H. and Colin, D.A. (1998) J. Membr. Biol. $162,209-216$.

[20] Tabor, S. and Richardson, C.C. (1987) Proc. Natl. Acad. Sci. USA 84, 4767-4771.

[21] Valeva, A., Weisser, A. and Walker, B. et al. (1996) EMBO J. 15, $1857-1864$.

[22] Ward, R.J., Palmer, S., Leonard, K. and Bhakdi, S. (1994) Biochemistry $33,7477-7484$.

[23] Woodin, A.M. (1960) Biochem. J. 75, 158-165. 